\title{
VOLTAMMETRIC DETERMINATION OF IRIDIUM IN ALLOYS USING XYLEN OL ORANGE
}

\author{
Ivan Franko National University of Lviv, \\ 6, Kyryla and M efodiya str., 79005 Lviv, Ukraine
}

Received: February 23, 2011 / Revised: M arch 11, 2011 / Accepted: M ay 31, 2011

(C) Kharchuk R., Tymoshuk O., 2011

\begin{abstract}
The possibility of iridium(IV) voltammetric determination using threephenylmethane dye (xylenol orange) has been investigated. The proposed technique has been tested using model solutions and in the process of iridium alloys analysis.
\end{abstract}

Keywords: iridium, voltammetric determination, threephenylmethane dye, xylenol orange.

\section{Introduction}

The scientific and technological advance stimulates the usage of materials having iridium among their components. The wide use of the mentioned metal is connected with its specific physico-chemical properties. The high efficiency of the products containing iridium in most cases is explained by its synergism with other components of platinum group. Therefore the tight control of the products quality, namely their macro- and microcomponents content is an urgent problem. The problem may be solved using different types of spectrophotometric analysis. However, their main drawback is low selectivity [1-4]. Voltammetric analysis is simple, express, accurate, and reproducible; it does not demand complicated pretreatment of the samples. All these facts make voltammetric analysis competitive among other physicochemicals methods. The development of modern methods of polarographic analysis, namely oscillographic type, as well as the use of organic reagents, allow to develop the techniques with improved chemical-analytic characteristics. Xylenol orange is one of threephenylmethane dyes used in voltammetry and other physico-chemical methods of analysis [5-8].

\section{Experimental}

\subsection{Starting Reagents}

All reagents were of analytical grade. The solution of xylenol orange was prepared using the certified reagent of HemaPol firm.
To obtain the chloride solution of iridium(IV) the method of metal iridium with oxidative mixture $\mathrm{NaNO}_{3}+\mathrm{NaOH}$ alloying was used. Then the obtained alloy was dissolved in chloride acid. The solutions were identified by the comparison of their absorption spectra with absorption spectra of $\operatorname{Ir}(\mathrm{IV})$ described in the literature [9-10]. Because of mechanical losses the iridium content was controlled using titration method (iodometry) [3].

The analyzed alloys were synthesized and their crystal structures were determined at the Department of Inorganic Chemistry of Ivan Franko National University of Lviv [11].

\subsection{Equipment}

Voltammetric investigations were carried out using CLA-03 oscillopolarograph in three-electrode thermostated cell: electrode-indicator, cathode - drop mercury electrode (d.m.e.); reference electrode, anode mercury chloride (saturated calomel) electrode (m.c.e.) and auxiliary electrod - platinum. The values of peak potentials in the maxima were determined using digital voltammeter B7-21 with the accuracy of $\pm 1 \mathrm{mV}$. The dissolved oxygen was removed from the the investigated solutions by argon passed for $15 \mathrm{~min}$. The medium acidity was controlled using $\mathrm{pH}-150 \mathrm{M}$ pH-meter with combination glass electrode.

\section{Results and Discussion}

Ir(IV) solutions were investigated using oscillograph voltammetry within the concentration range of $8.0 \cdot 10^{-3}$ to $1.0 \cdot 10^{-7} \mathrm{~mol} / \mathrm{l}$. The results are represented in Fig. 1 .

There are polarograph peaks in aqueous solutions

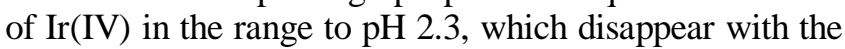
further increase of $\mathrm{pH}$. We connect this fact with the formation of electroinactive forms of platinum metal ions as a result of aquatic and hydrolysis processes. The dependence of potential of the reduction peak upon the 
medium acidity has a linear character with a straight slope of $69 \mathrm{mV} / \mathrm{pH}$ indicating the hydrogen ions participation in the electrochemical process (Fig. 2a).

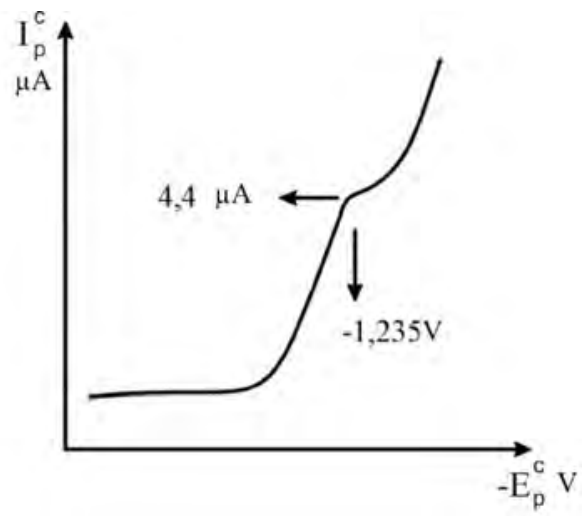

Fig. 1. Voltammetric characteristic of $\operatorname{Ir}(\mathrm{IV})$ solution reduction. $C_{I r(\mathrm{IV})}=1.0 \cdot 10^{-4} \mathrm{M} ; \mathrm{C}_{\mathrm{NaClO} 4}=0.16 \mathrm{M} ; \mathrm{pH}$ is 1.5

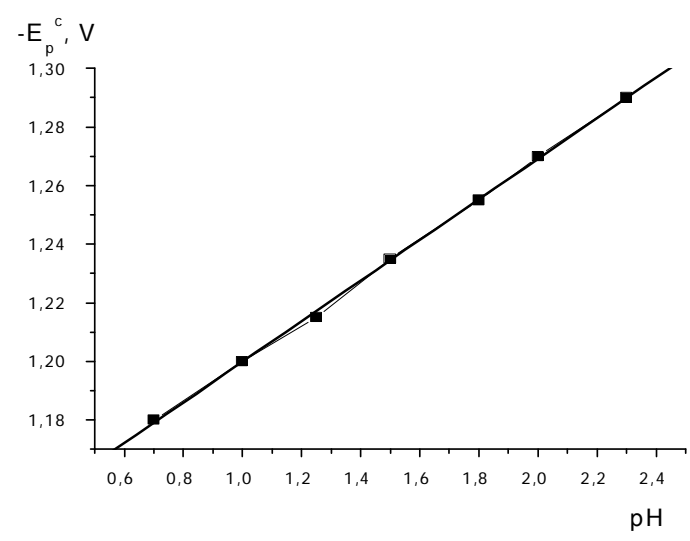

a

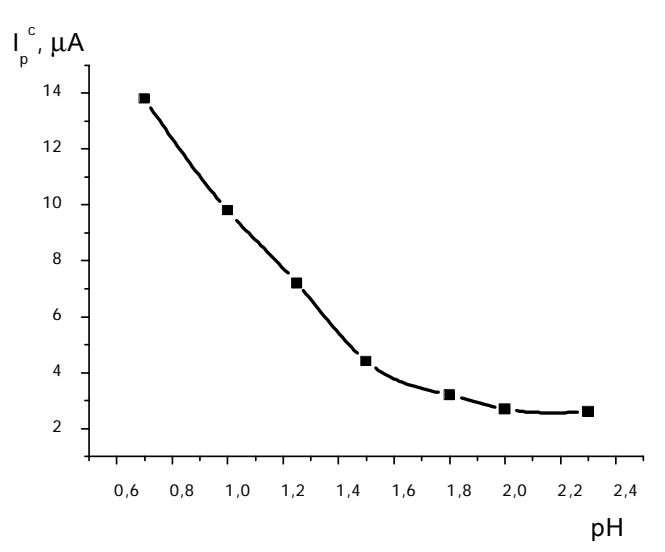

$\mathrm{b}$

Fig. 2. Dependence of voltammetric characteristics of $\operatorname{Ir}(\mathrm{IV})$ ions reduction: peak potential (a) and current strength (b).

$$
V=0.5 \mathrm{~V} / \mathrm{s}, C_{I r(\mathrm{IV})}=1.0 \cdot 10^{-4} \mathrm{M} ; C_{\mathrm{NaClO}}=0.16 \mathrm{M}
$$

The rate criterion (Table 1) shows that slope angle tangency of the dependence $\lg \left(I_{p}^{c} / S\right)-\lg V$ a is less than 0.5 indicating the diffusive nature of current with kinetic limits. The effect of kinetic limits increases with the decrease of the medium acidity. The slope angle tangency of the rate criterion decreases with the decrease of solution $\mathrm{pH}$ indicating the priority of a chemical reaction over. Such reaction preceding the electrochemical process may be protonization, aquatation, hydrolysis, or polymerization of $\operatorname{Ir}(\mathrm{IV})$ complexes.

Table 1

\section{Dependence of rate criterion upon the medium acidity for $\operatorname{Ir}(I V)$ solutions reduction}

\begin{tabular}{|c|c|c|c|c|}
\hline background $\mathrm{pH}$ & 1.0 & 1.5 & 2.0 & 2.3 \\
\hline$\left(\mathrm{Na}^{+}+\mathrm{H}^{+}\right)+\mathrm{Cr}$ & 0.33 & 0.29 & 0.27 & 0.15 \\
\hline \\
Note: $C_{I r(\mathrm{IV})}=1.0 \cdot 10^{-4} \mathrm{M} ; \mathrm{C}_{\mathrm{NaClO} 4}=0.16 \mathrm{M}$
\end{tabular}

The dependence of reduction current strength upon $\operatorname{Ir}(\mathrm{IV})$ ions concentration has a linear character. This fact was used for the development of analytic technique.

Xylenol orange (XO) is reduced at d.m.e. by two or three stages depending upon polarographic conditions (Fig. 3).
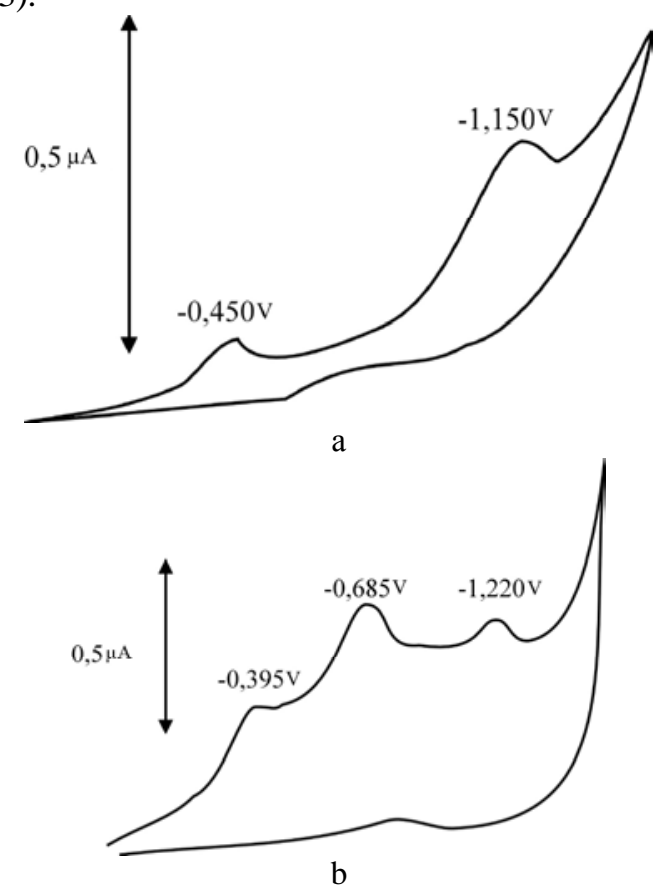

Fig. 3. Voltammetric characteristic of xylenol orange reduction in aqueous solutions: $\mathrm{pH}=2.0$ (a) and $\mathrm{pH}=7.1$ (b).

$$
C_{X O}=1.0 \cdot 10^{-3} \mathrm{~mol} / \mathrm{l}
$$

During the introduction of the dye into the solution with $\operatorname{Ir}(\mathrm{IV})$ ions the "exaltation" of cathode 
current of metal reduction takes place. The maximum increase in current is observed at the ratio $\mathrm{Me}: \mathrm{HR} \approx 1: 2$. Cathode current increases three times giving the possibility to improve the metrological characteristics of platinum metal determination (Table 2) at $\mathrm{pH} 1.0$.

Table 2

Metrological characteristics of voltammetric determination of $\operatorname{Ir}(\mathrm{IV})$ ions using xylenol orange

\begin{tabular}{|l|c|}
\hline $\begin{array}{l}\text { Linearity limits of } I_{p}^{c}(\mu \mathrm{A}) \text { from } C_{I r} \\
(\mathrm{~mol} / \mathrm{l})\end{array}$ & $5.0 \cdot 10^{-4}-1.0 \cdot 10^{-6}$ \\
\hline Equation of graduated diagram & $\begin{array}{l}I_{p}^{c}=0.11+ \\
+3.03 \cdot 10^{5} C\end{array}$ \\
\hline Correlation coefficient $R$ & 0.9969 \\
\hline $\begin{array}{l}\text { Lower limit of } C_{\min } \text { determination, } \\
\mathrm{mol} / \mathrm{l}\end{array}$ & $7.52 \cdot 10^{-7}$ \\
\hline
\end{tabular}

Researches of the selectivity of voltammetric determination of $\operatorname{Ir}(\mathrm{IV})$ using xylenol orange (Table 3) show that ions of non-platinum metals, as well as two hundred-fold excess of osmium and fifty-fold excess of palladium do not impede the determination. Instead, the technique is characterized by low selectivity concerning $\mathrm{Ru}(\mathrm{IV}), \mathrm{Rh}(\mathrm{III})$ and $\mathrm{Pt}(\mathrm{IV})$.

Table 3

Selectivity of Ir (IV) voltammetric determination using xylenol orange

\begin{tabular}{|c|c|c|c|}
\hline Ion & $\operatorname{Ir}(\mathrm{IV}):$ ion & Ion & $\operatorname{Ir}(\mathrm{IV})$ : ion \\
\hline $\mathrm{Pb}(\mathrm{II})$ & $1: 50$ & $\mathrm{Ru}(\mathrm{IV})$ & $1: 1$ \\
\hline $\mathrm{Zn}(\mathrm{II})$ & $1: 40$ & $\mathrm{Rh}(\mathrm{III})$ & $1: 0.1$ \\
\hline $\mathrm{Cd}(\mathrm{II})$ & $1: 50$ & $\mathrm{Pt}(\mathrm{IV})$ & $1: 1$ \\
\hline $\mathrm{Ca}(\mathrm{II})$ & $1: 200$ & Os(IV) & $1: 200$ \\
\hline $\operatorname{Mg}(\mathrm{II})$ & $1: 200$ & $\mathrm{Pd}(\mathrm{II})$ & $1: 50$ \\
\hline $\mathrm{Al}(\mathrm{III})$ & $1: 50$ & $\mathrm{Cl}^{-}$ & $1: 500$ \\
\hline $\mathrm{Fe}(\mathrm{III})$ & $1: 50$ & $\mathrm{I}^{-}$ & $1: 50$ \\
\hline $\mathrm{Ni}$ (II) & $1: 20$ & $\mathrm{NO}_{3}^{-}$ & $1: 500$ \\
\hline $\mathrm{Cu}(\mathrm{II})$ & $1: 50$ & $\mathrm{ClO}_{4}^{-}$ & $1: 500$ \\
\hline Co(II) & $1: 20$ & $\mathrm{BrO}_{3}^{-}$ & $1: 50$ \\
\hline $\mathrm{Ga}(\mathrm{III})$ & $1: 20$ & $\mathrm{SCN}^{-}$ & $1: 100$ \\
\hline $\mathrm{Tb}(\mathrm{III})$ & $1: 20$ & $\mathrm{Cr}_{2} \mathrm{O}_{7}^{2-}$ & $1: 100$ \\
\hline $\mathrm{Gd}(\mathrm{III})$ & $1: 30$ & $\mathrm{CH}_{3} \mathrm{COO}^{-}$ & $1: 500$ \\
\hline
\end{tabular}

\subsection{Technique of Ir(IV) Voltammetric Determination Using Xylenol Orange}

$2.0 \mathrm{ml}$ of $\mathrm{NaCl}$ solution (concentration $2.0 \mathrm{~mol} / \mathrm{l}$ ) and $\operatorname{Ir}(\mathrm{IV})$ solution (calculated in such a way that the end concentration of $\operatorname{Ir}(\mathrm{IV})$ ions were within $5.0 \cdot 10^{-4}$ $1.0 \cdot 10^{-6} \mathrm{~mol} / \mathrm{l}$ ) are loaded into a $25 \mathrm{ml}$ flask. Then $1.0 \mathrm{ml}$ of green solution of threephenylmethane dye with the concent-ration of $1.0 \cdot 10^{-3} \mathrm{~mol} / \mathrm{l}$ is added. Distilled water is poured till the total volume becomes $\sim 20 \mathrm{ml}$. The $\mathrm{pH}$ is established as 1.0 using $\mathrm{HCl}$ and $\mathrm{NaOH}$ solutions (not entering the alkaline area!) and distilled water is added to the mark. The medium acidity is controlled by $\mathrm{pH}$-meter and more exact $\mathrm{pH}$ value is established if necessary. The difference between $\mathrm{pH}$ for parallel experiments must be $\leq 0.1$. The investigated solution is transferred into an electrolyzer and dissolved oxygen is removed by a barbotage of purified argon through the cell for $15 \mathrm{~min}$. Then the voltammetric curves are obtained at the polarizing range of $(-0.5)-(-1.5) \mathrm{V}$ and the polarization voltage rate of $0.5 \mathrm{~V} \cdot \mathrm{s}^{-1}$.

\subsection{Technique Approbation}

The correctness of $\operatorname{Ir}(\mathrm{IV})$ voltammetric determination was verified using the "introduced-determined" method on model solutions. One can see from Table 4 that the technique is characterized by good reproducibility and determination correctness.

Table 4

Correctness of $\operatorname{Ir}(\mathrm{IV})$ voltammetric determination using xylenol orange $\left(C_{X O}=1 \cdot 10^{-3} \mathrm{M} ; C_{b a c k g .}=0.16 \mathrm{M} ; \mathrm{pH}=\right.$ $1.0 ; V=0.5 \mathrm{~V} / \mathrm{s} ; n=5 ; p=0.95)$

\begin{tabular}{|c|c|c|c|}
\hline \multirow{2}{*}{$\begin{array}{l}\text { Composition of } \\
\text { matrix solution }\end{array}$} & \multirow{2}{*}{$\begin{array}{c}\text { Introduced } \\
\text { Ir(IV) } \\
\mu \mathrm{g}\end{array}$} & \multicolumn{2}{|c|}{ Found $\operatorname{Ir}(\mathrm{IV}), \mathrm{mcg}$} \\
\hline & & $\begin{array}{c}\mathrm{m}(\mathrm{Ir}(\mathrm{IV})) \\
\mu \mathrm{g}\end{array}$ & $S_{r}$ \\
\hline \multirow{5}{*}{$\begin{array}{c}350 \mu \mathrm{g} \mathrm{Co}(\mathrm{II}) \\
250 \mu \mathrm{g} \mathrm{Fe}(\mathrm{III}) \\
30 \mu \mathrm{g} \mathrm{Pd}(\mathrm{II})\end{array}$} & \multirow{5}{*}{10.0} & 9.80 & \multirow{5}{*}{0.019} \\
\hline & & 9.75 & \\
\hline & & 9.92 & \\
\hline & & 9.83 & \\
\hline & & 9.91 & \\
\hline \multirow{5}{*}{$\begin{array}{l}350 \mu \mathrm{g} \mathrm{Cd}(\mathrm{II}) \\
250 \mu \mathrm{g} \mathrm{Ni}(\mathrm{II}) \\
250 \mu \mathrm{g} \mathrm{Zn(II)}\end{array}$} & \multirow{5}{*}{10.0} & 9.87 & \multirow{5}{*}{0.015} \\
\hline & & 9.84 & \\
\hline & & 9.93 & \\
\hline & & 9.96 & \\
\hline & & 9.81 & \\
\hline \multirow{5}{*}{$\begin{array}{l}250 \mu \mathrm{g} \mathrm{Ca}(\mathrm{II}) \\
350 \mu \mathrm{g} \mathrm{Al}(\mathrm{II}) \\
250 \mu \mathrm{g} \mathrm{Pb}(\mathrm{II})\end{array}$} & \multirow{5}{*}{10.0} & 9.88 & \multirow{5}{*}{0.017} \\
\hline & & 9.92 & \\
\hline & & 9.79 & \\
\hline & & 9.80 & \\
\hline & & 9.92 & \\
\hline
\end{tabular}

\subsection{Ir(IV) Voltammetric Determination in Alloys}

$0.10-0.05 \mathrm{~g}$ of alloy is dissolved in $10 \mathrm{ml}$ of $\mathrm{HCl}+\mathrm{HNO}_{3}(1: 1)$ mix. The obtained solution is evaporated to wet salts and again dissolved in $50 \mathrm{ml}$ of $\mathrm{HCl}$ ( $3.0 \mathrm{~mol} / \mathrm{l})$. If the alloy dissolves incompletely sintering of the new sample with $\mathrm{NaOH}+\mathrm{NaNO}_{3}(1: 3)$ oxidative mix is carried out. The obtained alloy is dissolved in $\mathrm{HCl}$ of $3.0 \mathrm{~mol} / \mathrm{l}$ concentration. Then it is placed in $250 \mathrm{ml}$ 
volumetric flask and distilled water is added to the mark. If necessary, the solution with iridium lower concentration is prepared. The aliquot of concentrated solution is placed in $100.0 \mathrm{ml}$ flask and $\mathrm{HCl}$ solution $(1.0 \mathrm{~mol} / \mathrm{l})$ is added to the mark.

For the analysis $2.0 \mathrm{ml}$ of $\mathrm{NaCl}$ solution $(2.0 \mathrm{~mol} / \mathrm{l})$ and aliquot of the analyzed solution are placed into $25.0 \mathrm{ml}$ flask. The amount of the analyzed solution is calculated to obtain $\operatorname{Ir}(\mathrm{IV})$ ions concentration of $1.0 \cdot 10^{-6}-$ $5.0 \cdot 10^{-4} \mathrm{~mol} / \mathrm{l}$. Fresh solution of xylenol orange is added to reach 5-10-fold molar excess. The voltammetric determination is the same as for iridium determination in model mixtures.

Table 5

Ir(IV) determination

in alloys using xylenol orange

\begin{tabular}{|c|c|c|}
\hline Sample mass, $\mathrm{g}$ & $\mathrm{Ir}$ content, \% & $S_{r}$ \\
\hline \multicolumn{3}{|c|}{$\mathrm{Tb}_{2} \mathrm{Ir}_{3} \mathrm{Al}_{9}(50.70 \%)$} \\
\hline 0.0790 & 50.62 & 0.020 \\
\hline 0.0630 & 50.73 & 0.018 \\
\hline \multicolumn{3}{|c|}{$\mathrm{Ga}_{2} \mathrm{Ir}_{3} \mathrm{Al}_{9}(60.13 \%)$} \\
\hline 0.0885 & 60.22 & 0.019 \\
\hline & 60.20 & 0.018 \\
\hline
\end{tabular}

\section{Conclusions}

The possibility of iridium (IV) voltemmetric determination using triphenylmethane dye - xylenol orange - has been examined. It has been established that base metals do not hinder the determination. Moreover, $\mathrm{Ru}(\mathrm{IV}), \mathrm{Rh}(\mathrm{III})$ and $\mathrm{Pt}(\mathrm{IV})$ ions show some catalytic effect. The investigation results were tested on the model solutions and during iridium alloys analysis.

\section{References}

[1] Bimish F.: Analitichecskaya Khimiya Blagorodnykh Metallov. Mir, Moskwa 1969.

[2] Zolotov Yu., Varshal G. and Ivanova V. (Eds.): Analiticheskaya Khimiya Metallov Platinovoy Grupy. Editorial URSS, Moskwa 2003.

[3] Ginzburg S., Ezerskaya N., Prokofieva I. et al.: Analiticheskaya Khimiya Platinovyh Metallov. Nauka, Moskwa 1972.

[4] Gurieva R. and Savvin S.: Zh. Anal. Khimii, 1995, 50, 1150.

[5] Tihonov V.: Zh. Anal. Khimii, 1986, 41, 1353.

[6] Byhovcova T. and Byhovcova I.: Zh. Anal. Khimii, 1987, 42, 1247.

[7] Trutneva L., Shvoeva O. and Savvin S.: Zh. Anal. Khimii, 1989, 44, 1804.

[8] Antonova T., Vershinin V. and Dedkov Yu.: Zh. Anal. Khimii, 2005, 60, 278.

[9] Ezerskaya N. and Kiseleva I.: Zh. Anal. Khimii, 2001, 56, 967.

[10] Nazarenko V., Antonovych V. and Nevskaya E.: Gidrolyz Ionov Metallov v Razbavlennyh Rastvorah. Atomizdat, Moskwa 1974.

[11] Lucyshyn Yu., Tokaichuk Ya., Demchenko P. and Gladyshevsky R.: Visnyk Lviv. Universitetu, Ser.Khim., 2010, 51, 52.

\section{ВОЛЬТАМПЕРОМЕТРИЧНЕ ВИЗНАЧЕННЯ ІРИДІЮ У СПЛАВАХ ЗА ДОПОМОГОЮ КСИЛЕНОЛОВОГО ОРАНЖЕВОГО}

Анотація. Досліджено можливість вольтамперометричного визначення іридію(IV) за допомогою трифенілметанового барвника - ксиленолового оранжевого. Проведено апробацію запропонованої методики на модельних розчинах та при аналізі іридієвих сплавів.

Ключові слова: іридій, вольтамперометричне визначення, трифенілметанові барвники, ксиленоловий оранжевий. 